\title{
Monitoring of unbound protein in vesicle suspensions with off-null ellipsometry
}

Citation for published version (APA):

Giesen, P. L. A., Willems, G. M., Hemker, H. C., Stuart, M. C. A., \& Hermens, W. T. (1993). Monitoring of unbound protein in vesicle suspensions with off-null ellipsometry. Biochimica et Biophysica Actabiomembranes, 1147(1), 125-131. https://doi.org/10.1016/0005-2736(93)90322-Q

Document status and date:

Published: 08/04/1993

DOI:

10.1016/0005-2736(93)90322-Q

Document Version:

Publisher's PDF, also known as Version of record

\section{Please check the document version of this publication:}

- A submitted manuscript is the version of the article upon submission and before peer-review. There can be important differences between the submitted version and the official published version of record.

People interested in the research are advised to contact the author for the final version of the publication, or visit the DOI to the publisher's website.

- The final author version and the galley proof are versions of the publication after peer review.

- The final published version features the final layout of the paper including the volume, issue and page numbers.

Link to publication

\footnotetext{
General rights rights.

- You may freely distribute the URL identifying the publication in the public portal. please follow below link for the End User Agreement:

www.umlib.nl/taverne-license

Take down policy

If you believe that this document breaches copyright please contact us at:

repository@maastrichtuniversity.nl

providing details and we will investigate your claim.
}

Copyright and moral rights for the publications made accessible in the public portal are retained by the authors and/or other copyright owners and it is a condition of accessing publications that users recognise and abide by the legal requirements associated with these

- Users may download and print one copy of any publication from the public portal for the purpose of private study or research.

- You may not further distribute the material or use it for any profit-making activity or commercial gain

If the publication is distributed under the terms of Article $25 \mathrm{fa}$ of the Dutch Copyright Act, indicated by the "Taverne" license above, 


\title{
Monitoring of unbound protein in vesicle suspensions with off-null ellipsometry
}

\author{
Peter L.A. Giesen ${ }^{a}$, George M. Willems ${ }^{a}$, H. Coenraad Hemker ${ }^{b}$, Marc C.A. Stuart ${ }^{c}$ \\ and Wim Th. Hermens ${ }^{\text {a }}$ \\ ${ }^{a}$ Cardiovascular Research Institute Maastricht, University of Limburg, Maastricht (The Netherlands), ${ }^{b}$ Department of Biochemistry, \\ University of Limburg, Maastricht (The Netherlands) and ' ${ }^{C}$ EM-unit, Department of Pathology, University of Limburg, \\ Maastricht (The Netherlands)
}

(Received 8 September 1992)

(Revised manuscript received 23 December 1992)

Key words: Blood coagulation; Lipid membrane; Dissociation constant; Ellipsometry

In studies on the binding of proteins to small unilamellar phospholipid vesicles (SUV), the concentration of unbound protein usually remains unknown, because the vesicles cannot be separated from the bulk solution. In the present study, this limitation was overcome by addition of a supported planar phospholipid bilayer to the cuvette containing a vesicle suspension. Ellipsometric measurement of the protein adsorption velocities on this bilayer allowed determination of the concentrations of unbound protein. At high protein concentrations the adsorption is rapidly completed and the usual null-ellipsometry is too slow to obtain well-defined initial adsorption rates. Therefore, an off-null technique was developed, allowing measurement of the adsorbed protein mass at time intervals of $20 \mathrm{~ms}$. Binding of prothrombin and coagulation factor Xa was measured in SUV suspensions prepared from a $20 \%$ dioleoylphosphatidylserine (DOPS) and $80 \%$ dioleoylphosphatidylcholine (DOPC) phospholipid mixture. For prothrombin, a dissociation constant $K_{\mathrm{d}}=140 \pm 27 \mathrm{nM}$ (mean \pm S.E.) and maximal surface concentration $\Gamma_{\max }=(8.9 \pm 0.8) \cdot 10^{-3}$ mole of protein per mole of lipid, were obtained. For factor Xa, these values were $K_{\mathrm{d}}=49.6 \pm 6.3 \mathrm{nM}$ and $\Gamma_{\max }=(23.0 \pm 1.4) \cdot 10^{-3}$ mole of protein per mole of lipid. These binding parameters are similar to those obtained earlier for planar bilayers. Apparently, the binding of factor $\mathrm{Xa}$ and prothrombin is not dependent on surface curvature.

\section{Introduction}

Lipid-protein interactions play a significant role in blood coagulation and most experiments in this area of research have been performed with suspensions of small unilamellar phospholipid vesicles (SUV). Such vesicles are prepared by sonication of phospholipid mixtures $[1,2]$ and have $10-40 \mathrm{~nm}$ diameter with a high surface curvature. After the introduction of (stoppedflow) light scattering in the study of binding of coagulation factors $X$ and prothrombin to SUV [3-6], most studies on lipid-protein interactions in blood coagulation have been performed with this technique. However, a comparison with results from techniques based on planar membranes, such as ellipsometry or adsorption of radiolabeled proteins to Langmuir-Blodgett layers, revealed conflicting results [7]. Also, several stud-

Correspondence to: P.L.A. Giesen, Cardiovascular Research Institute Maastricht, University of Limburg, P.O. Box 616, $6200 \mathrm{MD}$, Maastricht, The Netherlands. ies demonstrated effects of vesicle size on the binding parameters of proteins [8-10].

Measurement of protein binding by light scattering in SUV suspensions is based on enhancement of the scattering when vesicle mass is increased by protein adsorption. This technique does not allow direct measurement of the concentration of unbound protein, because SUV cannot be separated routinely from the buffer solution. In the present study this limitation is overcome by use of ellipsometry. On macroscopic phospholipid-coated surfaces most proteins, including factor $\mathrm{Xa}$ and prothrombin, show transport-limited initial adsorption, with an adsorption rate proportional to the free protein concentration and a mass transfer coefficient $\Delta$, depending on the flow conditions and the protein diffusion constant $[11,12]$. Measurement of the adsorption rate of protein on a planar phospholipid bilayer, deposited on a silicon slide, thus allows direct measurement of the buffer concentration of protein.

Normally, ellipsometry is a null-method with two polariser prisms, $\mathrm{P}$ and $\mathrm{A}$, rotated to positions resulting in maximal extinction of a laser beam $[12,13]$. These 
rotations require some time and, at high protein concentrations, the process is too slow to measure initial adsorption rates. The silicon slide, however, has the special property that by fixing $\mathrm{A}$ in its null-position and keeping $\mathrm{P}$ also in a fixed position, 12 degrees off-null, the change in adsorbed protein mass can be determined from the change in light intensity, sampled at 20 -ms intervals. In this way, initial adsorption rates could be accurately determined from measurements during only a few seconds.

Application of this method to SUV prepared from a $20 \%$ DOPS $/ 80 \%$ DOPC mixture demonstrated similar binding parameters as published earlier for the binding of factor $\mathrm{Xa}$ and prothrombin to planar mono- and double layers. It is concluded that the binding mechanisms of these coagulation factors, which are calciumdependent and probably do not require penetration of protein into the lipid bilayer, are not dependent on surface curvature.

\section{Materials and Methods}

\section{Proteins}

Bovine factor $\mathrm{X}$ and prothrombin were purified according to Refs. 14 and 15, respectively. Factor X was activated with Russell's viper venom (Sigma) [16]. Concentrations of factor Xa $\left(M_{\mathrm{r}}=44000\right)$ were determined by active site titration with $p$-nitrophenyl- $p^{\prime}$ guanidinobenzoate hydrochloride (ICN Nutritional Biochemicals) [17]. Concentrations of prothrombin $\left(M_{\mathrm{r}}\right.$ $=72000$ ) were determined similarly after complete activation to thrombin with factor $\mathrm{Xa}$, factor $\mathrm{Va}$ and phospholipid. All experiments were performed at room temperature $\left(20-22^{\circ} \mathrm{C}\right)$ in $0.05 \mathrm{M}$ Tris- $\mathrm{HCl}$ buffer $(\mathrm{pH}$ 7.5) containing $0.1 \mathrm{M} \mathrm{NaCl}, 3 \mathrm{mM} \mathrm{CaCl}_{2}$ and $0.5 \mathrm{gl}^{-1}$ bovine serum albumin (Sigma).

\section{Phospholipid vesicles and planar bilayers}

1,2-Dioleoyl-sn-glycero-3-phosphocholine (DOPC) and the corresponding phosphatidylserine (DOPS) were purchased from Sigma and Avanti Polar Lipids, respectively. Phospholipid concentrations were determined by phosphate analysis [18]. Suspensions of small unilamellar vesicles (SUV) were prepared by sonication of $20 \%$ DOPS / $80 \%$ DOPC and 40\% DOPS /60\% DOPC mixtures as described [1]. The size distribution of the vesicles was estimated by measurement of 100 vesicles on a micrograph made by thin film cryo-electron microscopy [19] at a magnification of $259000 \times$. It revealed that $97 \%$ of the vesicles have a diameter within the range of 10 to $40 \mathrm{~nm}$ and that $100 \%$ is unilamellar. Silicon slides were obtained and treated as described [11]. The slides were covered with a $40 \%$ DOPS $/ 60 \%$ DOPC bilayer by exposure to a vesicle suspension, as described [11]. This higher percentage of DOPS in the planar bilayer facilitates the determination of adsorption velocities, as explained below.

\section{Off-null ellipsometry}

Ellipsometry is based on the measurement of changes in light polarisation due to reflection [21]. These changes are strongly influenced by the presence of thin (0.1-10 nm) phospholipid and protein films on the reflecting surface. As described earlier [11], the reflecting surface is a phospholipid-coated silicon slide placed in a quartz cuvette with buffer. Normally, the changes in light polarisation are measured by null-ellipsometry: a laser beam passes a polarising prism $\mathbf{P}$, is reflected by the silicon slide, and then passes through a second polarising prism $\mathrm{A}$. The prisms $\mathrm{P}$ and $\mathrm{A}$ are rotated to positions such that the final light intensity, measured by a photodiode, is kept minimal. A computer, receiving the signal of the photodiode, controls the rotation of $\mathrm{P}$ and $\mathrm{A}$ with two stepping motors.

From the changes in null-positions of $\mathrm{P}$ and $\mathrm{A}$, during adsorption of protein to the slide, the adsorbed protein mass can be determined by means of the Lorentz-Lorenz relation [12,13]. However, one cycle of adjustments of $\mathrm{P}$ and $\mathrm{A}$ takes $5-10 \mathrm{~s}$. For the binding experiments in the present study, protein concentrations up to $300 \mathrm{nM}$ were used. For a value of the mass transfer coefficient $\Delta=2 \cdot 10^{-3} \mathrm{~cm} \mathrm{~s}^{-1}$ (see below) and a protein concentration of $300 \mathrm{nM}$, the adsorption of 1 pmol cm ${ }^{-2}$ of protein (25\% of $\Gamma_{\max }$ for prothrombin) will take $1.7 \mathrm{~s}$. Apparently, much faster sampling is required.

For a phospholipid-coated silicon slide, protein adsorption affects mainly the null-position of $P$, while the null-position of $\mathrm{A}$ is hardly changed. This property was used in the following measuring procedure (see Fig. 1):

(1) The null-positions $P_{\mathrm{s}}$ and $A_{\mathrm{s}}$ at the start of the experiment were determined for the silicon slide covered with the lipid bilayer, before any protein was adsorbed.

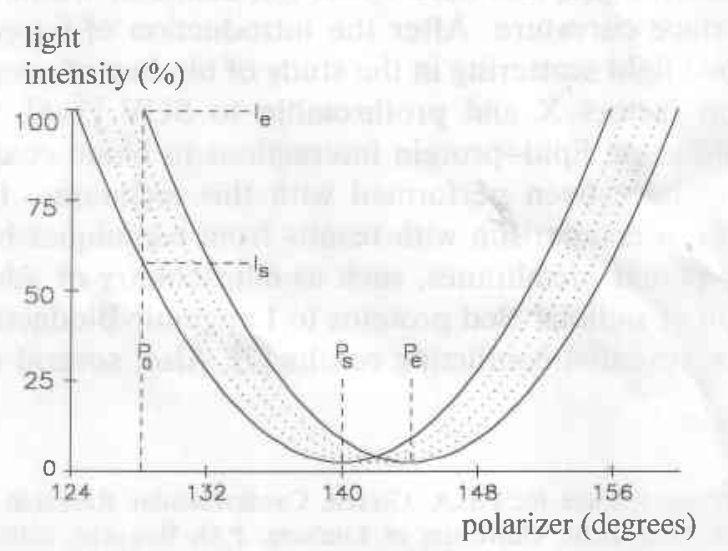

Fig. 1. Principles of off-null ellipsometry (see text). 
(2) The position of A was kept fixed at $A_{0}=A_{\mathrm{s}}$ and the position of $\mathrm{P}$ was fixed at a position $P_{0}$, usually at 12 degrees below $P_{\mathrm{s}}$. The light intensity $I_{\mathrm{s}}$ was then measured.

(3) Protein adsorption was started by addition of protein to the cuvette and the light intensity $I(t)$, as a function of time $t$, was recorded during ongoing adsorption.

(4) When a stable final intensity level $I_{\mathrm{e}}$ was attained, the final null-positions $P_{\mathrm{e}}$ and $A_{\mathrm{e}}$ were again measured by null-ellipsometry.

The light intensity $I(t)$, as a function of polariser and analyzer positions $P_{0}$ and $A_{0}$ and the time-dependent null-positions $P_{\mathrm{n}}(t)$ and $A_{\mathrm{n}}(t)$, is given by [21]:

$$
\begin{aligned}
I(t)= & K\left\{\sin ^{2}\left[A_{0}-A_{\mathrm{n}}(t)\right]\right. \\
& \left.+\sin \left[2 A_{0}\right] \sin \left[2 A_{\mathrm{n}}(t)\right] \sin ^{2}\left[P_{0}-P_{\mathrm{n}}(t)\right]\right\}
\end{aligned}
$$

where $K$ is an instrument-dependent constant.

Because $A_{\mathrm{n}}(t)$ hardly changes from $A_{0}=A_{\mathrm{s}}$, the first term can be neglected and, using the equality $2 \sin ^{2} x=1-\cos [2 x]$, the expression can be approximated by:

$I(t)=\frac{1}{2} K \sin ^{2}\left[2 A_{5}\right]\left\{1-\cos \left[2\left(P_{0}-P_{\mathbf{n}}(t)\right)\right]\right\}$

The value of $\cos \left[2\left(P_{0}-P_{\mathrm{n}}(t)\right)\right]$ is thus a linear function of $I(t)$ and can be obtained by linear interpolation:

$$
\begin{aligned}
\cos & {\left[2\left(P_{0}-P_{\mathrm{n}}(t)\right)\right] } \\
& =\frac{I(t)-I_{\mathrm{s}}}{I_{\mathrm{e}}-I_{\mathrm{s}}} \cos \left[2\left(P_{\mathrm{a}}-P_{\mathrm{e}}\right)\right]+\frac{I_{\mathrm{e}}-I(\mathrm{t})}{I_{\mathrm{e}}-I_{\mathrm{s}}} \cos \left[2\left(P_{0}-P_{\mathrm{s}}\right)\right]
\end{aligned}
$$

Eqn. 1 allows the calculation of the null-position $P_{\mathrm{n}}(t)$ from the light intensity $I(t)$, and the adsorbed protein mass $\Gamma$ was then calculated from the change in polariser position, as $\Gamma(t)=0.085 \cdot\left[P_{\mathrm{n}}(t)-P_{\mathrm{s}}\right] \mu \mathrm{g} \mathrm{cm}^{-2}$. This latter relation is an approximation of the full Lorentz-Lorenz relation [12,13], valid for the optical constants of the silicon surface and for small changes in $A_{\mathrm{n}}(t)$.

\section{Analysis of adsorption kinetics}

The protein content of the boundary layer at the surface is very small compared to the adsorption capacity of the surface and the transport capacity of diffusion. As a result, within a fraction of a second after addition of protein to the cuvette, a quasi-steady state will be formed at the surface with $\mathrm{d} \Gamma / \mathrm{d} t=\Delta\left(C_{\text {bulk }}-\right.$ $C_{0}$ ), with $C_{\text {bulk }}$ the buffer concentration of protein, $C_{0}$ the concentration of protein at the surface and $\Delta$ an experimental constant depending on the flow conditions and the diffusion constant of the protein [12]. For initial adsorption rates, that is, for low surface coverage, local equilibrium can be described by the classical Langmuir expression [22] with a dissociation constant
$K_{\mathrm{d}}=C_{0}\left(\Gamma_{\max }-\Gamma\right) / \Gamma$. Eliminating $C_{0}$ from these expressions one obtains:

$$
\frac{\mathrm{d} \Gamma(t)}{\mathrm{d} t}=\Delta\left[C_{\text {bulk }}-\frac{\Gamma(t) K_{\mathrm{d}}}{\Gamma_{\max }-\Gamma(t)}\right]
$$

First, Eqn. 2 was used to determine the values of $\Delta$ and $K_{\mathrm{d}}$ from a separate series of experiments, without SUV and with known values of $C_{\text {bulk }}$, using a standard non-linear least-squares fit (BMDP Statistical Software, Los Angeles, Routine 3R, version 1988). Variability of estimated parameters is expressed as the standard error of estimate (S.E.), that is, the standard deviation of the estimated parameter. The value of $\Gamma_{\max }$ was not obtained from this fit but from separate measurements with high protein concentrations. Using these values of $\Delta, K_{\mathrm{d}}$ and $\Gamma_{\max }$, Eqn. 2 was again applied in the binding experiments with SUV, in order to estimate the concentration $C_{\text {bulk }}$ of unbound protein in the buffer. It should be realised that, in these experiments, $C_{\text {bulk }}$ is the only important parameter, because the parameters $K_{\mathrm{d}}$ and $\Gamma_{\max }$ in Eqn. 2 describe the binding to the $40 \%$ DOPS $/ 60 \%$ DOPC bilayer on the silicon slide and are not relevant for the binding to SUV.

From the values of $C_{\text {bulk }}$ obtained in this way, and the total protein concentrations added, the equilibrium concentrations $\Gamma_{\mathrm{eq}}$ of bound protein were calculated. The parameters $K_{\mathrm{d}}$ and $\Gamma_{\max }$ for the binding of proteins to SUV were then obtained from a non-linear fit, using the expression:

$\Gamma_{\text {eq }}=\frac{\Gamma_{\max } C_{\text {bulk }}}{C_{\text {bulk }}+K_{\mathrm{d}}}$

\section{Results}

\section{Experiments without vesicles}

Addition of protein or a vesicle suspension to the cuvette causes irregularities due to mixing, increased light scattering, temperature effects etc., and these mixing effects are recorded, due to the high sampling frequency. In order to minimize these irregularities, the dilutions were chosen such that $1 \mathrm{ml}$ of protein solution was added to a cuvette filled with $4 \mathrm{ml}$ of buffer, up to final concentrations of $25-150 \mathrm{nM}$ of factor $\mathrm{Xa}$ and $25-600 \mathrm{nM}$ of prothrombin. This relatively high sample volume promotes rapid mixing. Fig. 2 left panel shows three examples of adsorption of a high concentration of prothrombin in the presence of SUV; after $0.3 \mathrm{~s}$ mixing effects have passed and the remaining curve can be used to estimate initial adsorption rates. Stopped-flow light scattering experiments $[5,23]$ demonstrated equilibration of protein binding to SUV within this time interval. An example of the 

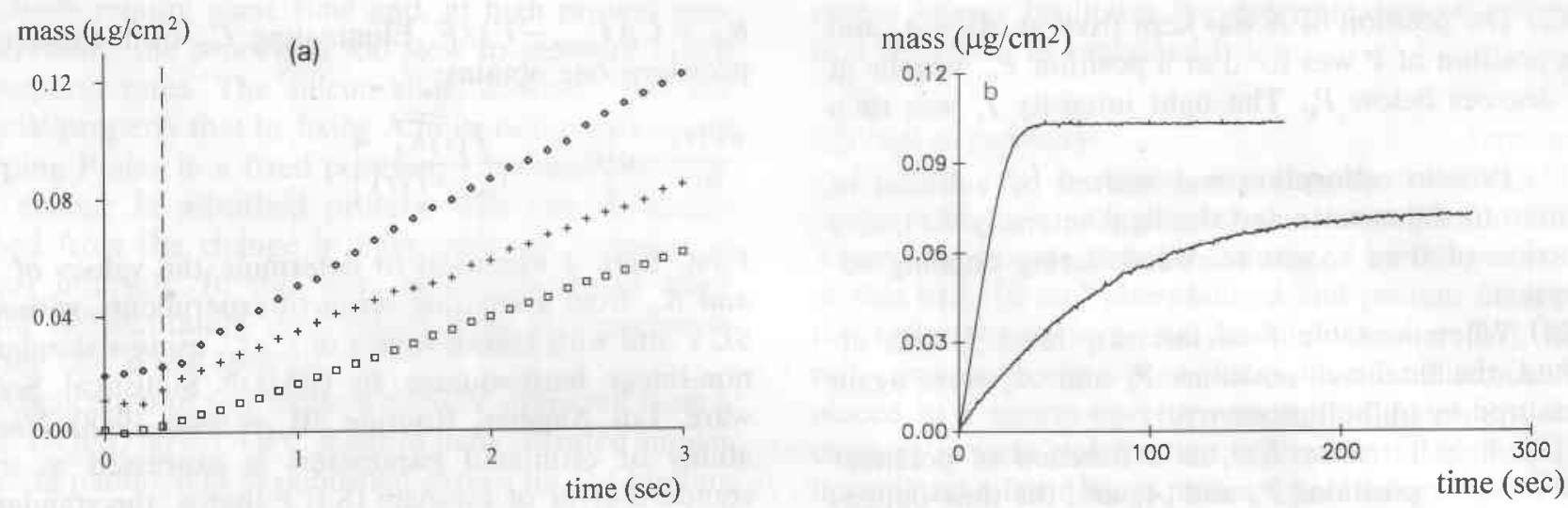

Fig. 2. (a) The first 3 seconds of adsorptions of prothrombin measured with off-null ellipsometry to a $40 \%$ DOPS $/ 60 \%$ DOPC bilayer in the presence of $50 \mu \mathrm{M} 20 \%$ DOPS $/ 80 \%$ DOPC SUV. Estimated free prothrombin concentrations were $\square: 164,+: 194$ and $\diamond: 286 \mathrm{nM}$. The vertical dashed line indicates $t=0.3 \mathrm{~s}$. At $t=0$ the various masses were arbitrarily set to $0,0.01$ and $0.02 \mu \mathrm{g} / \mathrm{cm}^{2}$. (b) Effect of SUV on protein adsorption, measured with off-null ellipsometry. Upper curve: adsorption of $25 \mathrm{nM}$ prothrombin in the absence of SUV to a $40 \%$ DOPS/ $60 \%$ DOPC planar bilayer. Lower curve: adsorption in the presence of $50 \mu \mathrm{M} 20 \%$ DOPS /80\% DOPC SUV.

adsorbed mass as a function of time is shown in the upper curve of the right panel of Fig. 2. Values of $\Gamma_{\max }$ for the $40 \%$ DOPS $/ 60 \%$ DOPC bilayer determined from saturating protein concentrations, were $\Gamma_{\max }=$ $10.5 \mathrm{pmol} \mathrm{cm}^{-2}$ and $\Gamma_{\max }=3.7 \mathrm{pmol} \mathrm{cm}^{-2}$ for factor $\mathrm{Xa}$ and prothrombin, respectively. Inserting these values into Eqn. 2 the initial adsorption rates $(\mathrm{d} \Gamma / \mathrm{d} t)_{\mathrm{t}=0}$ $=\Delta C_{\text {bulk }}$ could be determined, as a function of $C_{\text {bulk }}$, from fits restricted to low surface coverages $(<25 \%$ of $\left.\Gamma_{\max }\right)$ for which the adsorption can be described with the Langmuir formalism and Eqn. 2 remains valid. Fig. 3 shows the results from which values of $\Delta$ were determined. For the experimental conditions used, a stirrer of $1 \mathrm{~cm}$ diameter rotating at $1.2 \mathrm{~mm}$ distance from the adsorbing slide with $2300 \mathrm{rpm}$, values of $\Delta=(22.2 \pm 1.7) \cdot 10^{-4} \mathrm{~cm} \mathrm{~s}^{-1}$ and $\Delta=(19.6 \pm 1.9) \cdot$ $10^{-4} \mathrm{~cm} \mathrm{~s}^{-1}$ (mean \pm S.E.) were obtained for Factor $\mathrm{Xa}$ and prothrombin, respectively. The dissociation constants for binding to the $40 \%$ DOPS $/ 60 \%$ DOPC

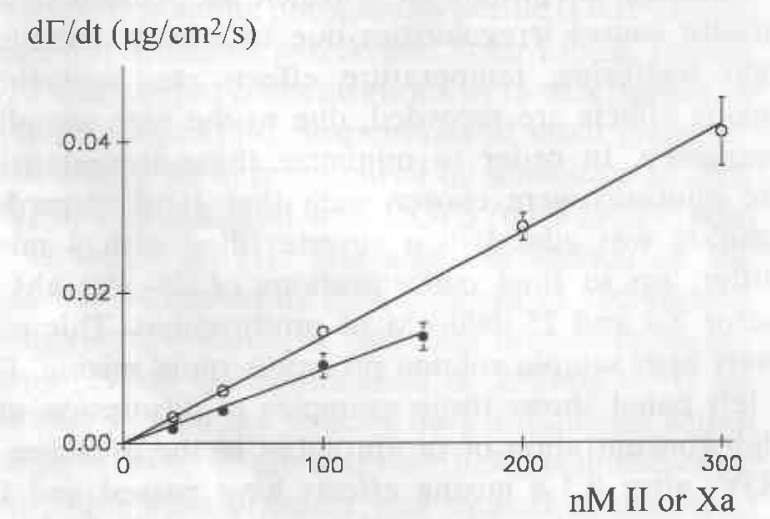

Fig. 3. Determination of initial adsorption rates as a function of buffer concentrations of protein. Upper curve: prothrombin. Lower curve: factor Xa. Symbols indicate mean values of four experiments. Standard errors are indicated. bilayer, obtained as a by-product from Eqn. 2, were $K_{\mathrm{d}}=13.3 \pm 1.8 \mathrm{nM}$ for factor $\mathrm{Xa}$ and $K_{\mathrm{d}}=31.6 \pm 3.9$ $\mathrm{nM}$ for prothrombin. These values are lower than for $20 \%$ DOPS $/ 80 \%$ DOPC (see below) and this implies that Eqn. 2 departs less rapidly from linearity and allows better determination of initial adsorption rates. For this reason, a DOPS content of $40 \%$ was chosen for the bilayer on the silicon slide.

\section{Experiments with SUV and factor Xa}

Fig. 2 right panel also shows the large effects of addition of SUV on the adsorption rates. These experiments were performed with total protein concentrations in the range of $25-300 \mathrm{nM}$, combined with 3,6 or $9 \mu \mathrm{M}$ of lipid, such that the concentrations of bound and unbound protein were of the same order of magnitude, as required for accurate estimation of the bound protein concentration from the total concentration and $C_{\text {bulk }}$. In order to minimize mixing effects, the

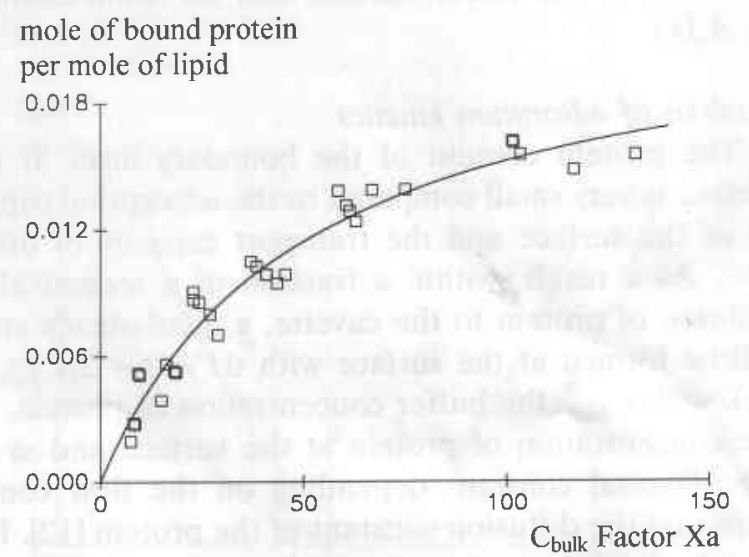

Fig. 4. Binding isotherm of coagulation factor Xa on SUV, prepared from $20 \%$ DOPS $/ 80 \%$ DOPC. Symbols indicate separate experiments. The best fitting binding isotherm is indicated. 
mole of bound protein

per mole of lipid

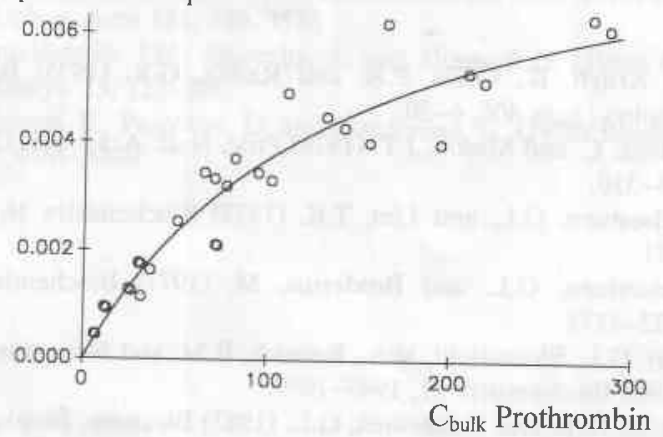

Fig. 5. Binding isotherm of prothrombin on SUV, prepared from $20 \%$ DOPS $/ 80 \%$ DOPC. Symbols indicate separate experiments. The best fitting binding isotherm is indicated.

protein/vesicle mixture was incubated for $10 \mathrm{~min}$ before it was added to the cuvette, choosing again $1 \mathrm{ml}$ of sample on $4 \mathrm{ml}$ of buffer. For protein concentrations exceeding $300 \mathrm{nM}$, aggregation of vesicles became apparent from turbidity in the cuvette. From the total buffer concentrations of lipid and protein, and the concentrations $C_{\text {bulk }}$ of unbound protein, the concentrations of bound protein, expressed as moles of protein per mole of lipid $\left(\mathrm{mol} \mathrm{mol}^{-1}\right)$ were calculated and the results are shown in Fig. 4 where each square represents one experiment. Fitting these results to Eqn. 3, values of $K_{\mathrm{d}}=49.6 \pm 6.3 \mathrm{nM}$ and $\Gamma_{\max }=(23 \pm$ 1.4) $\cdot 10^{-3} \mathrm{~mol} \mathrm{~mol}^{-1}$ were obtained.

\section{Experiments with SUV and factor II}

The total range of prothrombin concentrations was 25-500 nM combined with a phospholipid concentration of $50 \mu \mathrm{M}$. Results are presented in Fig. 5 and fitting these data to Eqn. 3 resulted in values of $K_{\mathrm{d}}=$ $140 \pm 27 \mathrm{nM}$ and $\Gamma_{\max }=(8.9 \pm 0.8) \cdot 10^{-3} \mathrm{~mol} \mathrm{~mol}^{-1}$.

\section{Discussion}

\section{Comparison with binding parameters from the literature}

The binding parameters found for SUV in the present study agree well with earlier published values for $20 \%$ DOPS $/ 80 \%$ DOPC planar membranes, measured by ellipsometry. For factor Xa, values of $K_{\mathrm{d}}=47 \mathrm{nM}$ and $\Gamma_{\max }=20 \cdot 10^{-3} \mathrm{~mol} \mathrm{~mol}^{-1}$ were obtained from the equilibrium binding isotherm [20], and similar measurements resulted in values of $K_{\mathrm{d}}=160 \mathrm{nM}$ and $\Gamma_{\max }=6 \cdot 10^{-3} \mathrm{~mol} \mathrm{~mol}^{-1}$ for prothrombin [24]. These values differ to some extent from the results of lightscattering experiments. Using again only data obtained with SUV prepared from PS /PC mixtures with $20-25 \%$ PS, reported values were $K_{\mathrm{d}}=114-200 \mathrm{nM}, \Gamma_{\max }=$ $(16-22) \cdot 10^{-3} \mathrm{~mol} \mathrm{~mol}^{-1}$ for factor $\mathrm{X}$ or factor $\mathrm{Xa}$ $[3,25,26]$, and $K_{\mathrm{d}}=300-500 \mathrm{nM}, \Gamma_{\max }=(11-15) \cdot 10^{-3}$ $\mathrm{mol} \mathrm{mol}^{-1}$ for prothrombin $[3,5,25]$.

The estimated $K_{\mathrm{d}}$ on SUV is the result of a fit to the data over the complete range of concentrations used in Figs. 4 and 5. However, effects like surface exclusion or molecular interaction can, at increasing surface coverage, play a significant role [22]. Therefore the fit was repeated for the range of concentrations below the estimated $K_{\mathrm{d}}$ (49.6 nM for Xa, $140 \mathrm{nM}$ for prothrombin). This resulted in values of $K_{\mathrm{d}}$ and $\Gamma_{\max }$ not deviating significantly from the original values: $K_{\mathrm{d}}=39 \pm 12.8 \mathrm{nM}$ with $\Gamma_{\max }=(19 \pm 4) \cdot 10^{-3}$ $\mathrm{mol} \mathrm{mol}^{-1}$ for factor $\mathrm{Xa}$ and $K_{\mathrm{d}}=164 \pm 67 \mathrm{nM}$ with $\Gamma_{\max }=(9.97 \pm 2.76) \cdot 10^{-3} \mathrm{~mol} \mathrm{~mol}^{-1}$ for prothrombin. It is concluded that binding of factor $\mathrm{Xa}$ and prothrombin can indeed be described approximately with a classical binding model with independent binding sites.

\section{Limitations of the presented technique}

The technique fails if the initial adsorption velocity cannot be estimated. For instance in the case of protein concentrations in the micromolar range, the adsorption velocities will be so high that a substantial proportion of $\Gamma_{\mathrm{eq}}$ is reached during the short period of mixing. On the other extreme, at unbound protein concentrations in the picomolar range, it takes hours before a sufficient amount of protein is transported toward the surface and adsorption velocities can be measured.

Another complication could occur if protein-carrying SUV would unload when they reach the planar surface and thereby could contribute to the measured rate of protein transport toward the surface. This was checked by addition of a large amount of vesicles to the cuvette which produced complete inhibition of adsorption (data not shown). Apparently diffusion of vesicles is slow compared to transport of protein from the buffer.

The scatter in the data presented in Figs. 4 and 5 is presumably the result of various experimental errors in adsorption rate, vesicle concentration and DOPS-percentage of the daily prepared lipid mixtures. It cannot be explained from the variation in simultaneously estimated $K_{\mathrm{d}}$ values, since the latter hardly influence the calculations.

\section{Lipid content and packing density of the bilayer leaflets in SUV}

It follows from simple geometrical considerations that for small vesicles like SUV, the outer bilayer leaflet must contain considerably more lipid than the inner leaflet. Several studies have estimated this difference at a factor of 1.8-2.3 for SUV prepared from pure DOPC or egg PC [1,27] and 2.3-3.2 for egg PC/brain PS [28,27] and egg PC/phosphatic acid (PA) mixtures [29]. The high surface curvature of SUV may also introduce differences in the mechanical properties, for instance due to bending stiffness [30], or pack- 
ing density of the bilayer. Indeed, lower phase-transition temperatures were found in SUV, compared to large unilamellar vesicles (LUV) prepared from the same lipids [31], and differences in packing density between SUV and planar bilayers have been suggested $[2,32]$. Such effects were mainly attributed to restriction of the available surface area per headgroup in the inner leaflet $[33,34]$. Higher binding affinities for protein binding to SUV, compared to LUV, has been reported for cytochrome $b_{5}$ [8], the complement complex C5b-7 [9] and the light chain of factor Va [10]. Binding of these proteins may be associated with insertion of part of the protein into the hydrocarbon core of the membrane and a more loose packing of the lipids in the outer monolayer of SUV could facilitate such hydrophobic interactions. The present study indicates that for peripheral, calcium-dependent, binding of proteins like factor $\mathrm{Xa}$ and prothrombin, the differences between SUV and planar bilayers do not result in significantly altered binding affinities.

Asymmetry of PS / PC ratio in the bilayer leaflets of SUV An asymmetric distribution of PS in the bilayer leaflets could change the binding affinity and thereby mask an effect of surface curvature. Data on this asymmetry of phospholipid distribution in the inner and outer bilayer leaflet of SUV are conflicting. This phenomenon has been characterised with the asymmetry coefficient $k_{\text {as }}=(\mathrm{PS} / \mathrm{PC})_{\text {in }} /(\mathrm{PS} / \mathrm{PC})_{\text {out }}$. A value of $k_{\text {as }}=2.1$ [28] for a $20 \%$ PS $/ 80 \%$ PC mixture may have been caused by preparation of SUV at $\mathrm{pH}=5$, because an earlier study [27] showed that $k_{\text {as }}$ changed from 1.1 to 1.9 when the $\mathrm{pH}$ was shifted from 7 to 5 . These results were obtained with NMR spectroscopy and differ from those obtained from dye binding or TNBS (2,4,6-trinitrobenzenesulfonic acid) adsorption [35], which showed preferential accumulation of PS in the outer monolayer. Such contradictory results were also reported for the distribution of PA and PC. Homogeneous distribution [29], and accumulation of PA in the outer layer [36] were both reported. The same is true for mixtures of phosphoglycerol (PG) and PC [37,38]. The asymmetry coefficient also tends to give a false impression of the size of the effect. For instance, a value of $k_{\mathrm{as}}=2$ for SUV prepared from $20 \%$ DOPS $/ 80 \%$ DOPC, would imply a change in the DOPS/DOPC ratio of the outer monolayer, containing twice as much lipid as the inner monolayer, from $20 \% / 80 \%$ to $15 \% / 85 \%$.

\section{Acknowledgement}

This work was supported by Grant 900-526-079 from the Netherlands Organisation for Scientific Research.

\section{References}

1 De Kruyff, B., Cullis, P.R. and Radda, G.K. (1975) Biochim. Biophys. Acta 406, 6-20.

2 Huang, C. and Mason, J.T. (1978) Proc. Natl. Acad. Sci. USA 75, 308-310.

3 Nelsestuen, G.L. and Lim, T.K. (1977) Biochemistry 16, 41644171.

4 Nelsestuen, G.L. and Broderius, M. (1977) Biochemistry 16, $4172-4177$.

5 Wei, G.J., Bloomfield, V.A., Resnick, R.M. and Nelsestuen, G.L. (1982) Biochemistry 21, 1949-1959.

6 Pusey, M.L. and Nelsestuen, G.L. (1983) Biochem. Biophys. Res. Commun. 114, 526-532.

7 Hermens, W.T., Kop, J.M.M. and Willems, G.M. (1988) in Coagulation and Lipids (Zwaal, R.F.A., ed.), pp. 73-97, CRC Press, Boca Raton, FL.

8 Greenhut, S.F., Bourgeois, V.R., Roseman, M.A. (1986) Biological Chemistry 261, 3670-3675.

9 Silversmith, R.E. and Nelsestuen, G.L. (1986) Biochemistry 25, $7717-7725$.

10 Abbott, A.J. and Nelsestuen, G.L. (1987) Biochemistry 26, 79948003.

11 Giesen P.L.A., Willems, G.M., Hemker, H.C. and Hermens, W.T. (1991) J. Biol. Chem. 266, 18720-18725.

12 Corsel, J.W., Willems, G.M., Kop, J.M.M., Cuypers, P.A. and Hermens, W.T. (1986) J. Colloid Interface Sci. 111, 544-554.

13 Cuypers, P.A., Corsel, J.W., Janssen, M.P., Kop, J.M.M., Hermens, W.T. and Hemker, H.C. (1983) J. Biol. Chem, 258, 24062431.

14 Fujikawa, K., Legaz, M.E. and Davie, E.W. (1972) Biochemistry $11,4882-4891$.

15 Owen, W.G., Esmon, C.T. and Jackson, C.M. (1974) J. Biol. Chem. 249, 594-605.

16 Fujikawa, K., Legaz, M.E. and Davie, E.W. (1972) Biochemistry 11, 4892-4899.

17 Smith, R.L. (1973) J. Biol. Chem. 248, 2418-2423.

18 Böttcher, C.J.F., Van Gent, C.M. and Pries, C. (1962) Anal. Chim. Acta 24, 203-207.

19 Frederik, P.M., Stuart, M.C.A., Bomans, P.H.H. and Busing, W.M. (1989) J. Microsc. 153, 81-92.

20 Giesen, P.L.A., Willems, G.M. and Hermens, W.T. (1991) J. Biol. Chem. 266, 1379-1382.

21 Azzam, R.M.A. and Bashara, N.M. (1977) Ellipsometry and polarized light, North Holland, Amsterdam.

22 Willems, G.M., Hermens, W.T. and Hemker, H.C. (1991) J. Biomater. Sci. Polymer Edn. 2, 217-226.

23 Krishnaswamy, S. (1988) J. Biol. Chem. 263, 3823-3834.

24 Kop, J.M.M., Cuypers, P. A, Lindhout, T., Hemker, H.C. and Hermens, W. Th. (1984) J. Biol. Chem. 259, 13993-13998.

25 Cutsforth, G.A., Whitaker, R.N., Hermans, J. and Lentz, B.R. (1989) Biochemistry 28, 7453-7461.

26 Krishnaswamy, S. (1990) J. Biol. Chem. 265, 3708-3718.

27 Berden, J.A., Barker, R.W. and Radda, G.K. (1975) Biochim. Biophys. Acta 375, 186-208.

28 Barsukow, L.I., Victorov, A.V., Vasilenko, I.A., Evstigneeva, R.P. and Bergelson, L.D. (1980) Biochim. Biophys. Acta 153-168.

29 Koter, M., De Kruijff, B., and Van Deenen, L.L.M. (1978) Biochim. Biophys. Acta 514, 255-263.

$30 \mathrm{Bo}$, L. and Waugh, R.E. (1989) Biophys. J. 55, 509-517.

31 Lichtenberg, D., Freire, E., Schmidt, C.F., Barenholz, Y., Felgner, P.L. and Thompson, T.E. (1981) Biochemistry 20, 34623467.

32 Chrzesczyk, A., Wishnia, A and Springer, C.S. (1977) Biochim. Biophys. Acta 470, 161-169. 
33 Carnie, S., Israelachvili, J.N. and Pailthorpe, B.A. (1979) Biochim. Biophys. Acta 554, 340-357.

34 Israelachvili, J.N., Marcelja, S. and Horn, R.G. (1980) Q. Rev. Biophys. 13, 121-200.

35 Massari, S., Pascolini, D. and Gradenigo, G. (1978) Biochemistry 17, 4465-4469.
36 Massari, S. and Pascolini, D. (1977) Biochemistry 16, 1189-1195. 37 Lentz, B.R., Alfort, D.R. and Dombrose, F.A. (1980) Biochemistry $19,2555-2559$.

38 Nordlund, J.R., Schmidt, C.F. and Thompson, T.E. (1981) Biochemistry $20,6415-6420$. 